\title{
Biosorption of Hexavalent Chromium by Bacteria Isolated from Salt Rich Tannery Wastes
}

\author{
E.H. El-Shatoury and S.T.M. Tolba \\ Microbiology Department, Faculty of Science, Ain Shams \\ University, Cairo, Egypt.
}

\begin{abstract}
TN THIS STUDY, two isolates capable of biosorption of $\mathrm{Cr}(\mathrm{VI})$ were isolated from chromium rich effluent treatment plant located at Magra Al-Oyoon, Old Cairo, Egypt. The abundance of bacteria residing in tannery waste water with high metal content was studied. Seventy-two bacterial isolates were recovered by direct plating; two of them were resistant to high chromium concentration (up to $30 \mathrm{mmol}$ chromate). According to the morphological, biochemical and the $16 \mathrm{~S}$ rRNA sequence analysis they were identified as Bacillus tequilensis and Planococcus citreus .
\end{abstract}

The atomic adsorption spectroscopy showed that reduction of chromate content in the cell free supernatant was $59.8 \%$ and $45.8 \%$ for Bacillus tequilensis and Planococcus citreus, respectively, after $24 \mathrm{hr}$ of incubation at $30^{\circ} \mathrm{C}$. Moreover, both scanning electron micrographs and EDX analysis showed accumulation of chromate on both isolates. Bacillus tequilensis and Planococcus citreus had high potential for hexavalent chromium removal and can be used for detoxification of waste containing hexavalent chromium along with other heavy metals in media with high salt concentration.

Keywords: Chromium, Heavy metals, Biosorption, SEM-EDX.

Chromium is widely used in a variety of industrial processes such as leather tanning, electroplating, dye and pigment manufacturing. It is mainly used as chromate and dichromate (Baldi et al., 1990). Chromium is a transition element with electronic configuration of $\left(\mathrm{Ar} 3 \mathrm{~d}^{5} 4 \mathrm{~s}^{1}\right)$. Although chromium exists in multiple valence states, hexavalant $\mathrm{Cr}(\mathrm{VI})$ and trivalent $\mathrm{Cr}(\mathrm{III})$ chromium are ecologically important because they are the most stable oxidation states in the natural environments (Megharaj et al., 2003). Industrial effluents containing chromium compounds are released directly or indirectly into the soil-water systems resulting in the contamination of the environments (Thacker et al., 2006). Cr (VI) is toxic to most organisms (Ganguli and Tripathi, 2002), it is listed as priority metal pollutant and is classified as a class A carcinogen by the US Environmental Protection Agency USEPA (Costa and Klein, 2006). Cr (III) is less mobile, less toxic and is mainly bound to organic matter in soil and aquatic environments (Becquer et al., 2003).

Due to the ubiquity, toxicity and occupational exposure of workers to chromium there is an interest in innovative, low cost methods for the remediation 
of $\mathrm{Cr}$ (VI) from contaminated environment (De Flora 2000). Reduction of $\mathrm{Cr}$ (VI) to chromium (III) may alter the toxicity and environment mobility of the metal. The chemical methods currently used to treat chromium involve the addition of reductants, and subsequent $\mathrm{pH}$ adjustment to neutral ranges to precipitate the less soluble $\mathrm{Cr}$ (III). These processes requires large amount of chemicals and results in a metal-containing chemical sludge that further imposes threat to the environment (Shakoori et al., 2000).

Biotechnological applications to remove chromate offer an advantage over the chemical procedure (Aravindhan et al., 2007). The major processes being investigated are the adsorption onto biological materials and dissimilarly reduction of metal ions from higher to lower valance state through enzymatic reaction (Lovely and Philips 1994).

Biotransformation of $\mathrm{Cr}$ (VI) to less toxic $\mathrm{Cr}$ (III) by chromate resistant and reducing bacteria has offered an ecological and economical option for chromate detoxification and bioremediation (Lira-Silva et al., 2011). Chromate resistance has been demonstrated by various bacterial species including Bacillus sp. (Camargo et al., 2004 and Liu et al., 2006), Pseudomonas sp. (Ganguli and Tripathi 2002 and Park et al., 2000), Desulfovibrio sp. (Mabbett and Macaskie 2001), Mycobacterium sp. (Pattanapipitpasal et al., 2001), Shewanells sp. (Myers et al., 2000 and Vaimajala et al., 2002), Arthrobacter sp. (Megharaj et al., 2003 and Asatiani et al., 2004).

Chromium discharge in the area of study is due to the practice of leather tanning where animal skins are treated with high salt and chromate concentrations to make them more durable and less susceptible to decomposition. The present study aims to isolate endogenous bacteria that are tolerant to high concentrations of salt and chromium to investigate their potential application in the bioremediation technology.

\section{Material and Methods}

\section{Sampling and bacterial isolation}

Ten samples were collected from a tannery plant in Magra Al-Oyoon area in Cairo, Egypt, They were divided in two-five sample groups; group A obtained from waste water after washing of leather with $\mathrm{K}_{2} \mathrm{Cr}_{2} \mathrm{O}_{7}$ pooled together, and group $\mathrm{B}$ from the skin shaves pooled. Both groups of samples were analyzed by the atomic absorption spectrophotometer to determine the total content of $\mathrm{Cr}$, $\mathrm{Cd}, \mathrm{Zn}, \mathrm{Pb}, \mathrm{Cu}, \mathrm{Fe}$. All samples were serially diluted and plated on LuriaBertani (LB) agar. A control sample from sterile field soil was run aside. The plates were incubated for $24 \mathrm{hr}$ at $30^{\circ} \mathrm{C}$, and bacterial count was recorded.

\section{Selection of most tolerant isolates}

LB agar medium supplemented with $\mathrm{K} 2 \mathrm{Cr} 2 \mathrm{O} 7$ (as $\mathrm{Cr} / \mathrm{VI}$ ) to a final concentrations ranging from $5 \mathrm{mmol}$ to $15 \mathrm{mmol}$ were prepared. The $\mathrm{Cr}$ (VI)

Egypt. J. Bot., 54, No.1 (2014) 
stock solutions were filter- sterilized with $0.22 \mu \mathrm{m}$ membrane filter papers (Millipore Corp., Bedford, MA). Groups A and B were serially diluted and inoculated on surface of plates containing $\mathrm{LB}$ as control plates and $\mathrm{LB}$ were amended with $\mathrm{K}_{2} \mathrm{Cr}_{2} \mathrm{O}_{7}$. The plates were incubated at $30^{\circ} \mathrm{C}$ in the dark and examined after $24 \mathrm{hr}$. Bacterial colonies were purified on LB agar containing 5 mmol $\mathrm{Cr}(\mathrm{VI})$ and incubated for $24 \mathrm{hr}$ at $30^{\circ} \mathrm{C}$. Bacterial isolates with distinctive morphology were recovered from $15 \mathrm{mmol} \mathrm{Cr}$ amended plates. These isolates were grown on LB broth containing $\mathrm{Cr}(\mathrm{IV})$ in concentrations ranging from 5 to $30 \mathrm{mmol}$.

\section{Determination of Chromium uptake}

Each bacterial culture was grown in an a flask containing $200 \mathrm{ml}$ LB medium supplemented with $15 \mathrm{mmol} \mathrm{K} \mathrm{Cr}_{2} \mathrm{O}_{7}$ before incubation (in triplicates) at $30^{\circ} \mathrm{C}$ in a shaking incubator at $120 \mathrm{rpm}$. The control sample was prepared aside without the addition of $\mathrm{K}_{2} \mathrm{Cr}_{2} \mathrm{O}_{7}$. Single cultures were removed after $6,12,18,24$ and $30 \mathrm{hr}$ of incbation, centrifuged and the cell free supernatants were analyzed for determination of total chromium using atomic absorption spectrophotometer at Ain Shams University.

\section{Identification of bacterial isolates}

Morphological examination, biochemical tests, and 16S RNA sequence analysis were carried out to identify the chromium tolerant isolates. Universal bacterial primers corresponding to $E$. coli positions $27 \mathrm{~F}$ and $519 \mathrm{R}$ were used for polymerase chain reaction (PCR) amplification of the 16S rRNA gene (Edwards et al., 1989). PCR Dream Taq master mix (Fermentas) was used according the manufacturer's instructions. The PCR product was analyzed on $1 \%$ agarose, purified with Quiagen gel extraction kit and sequenced using ABI sequencer. The nucleotide sequences were submitted in ncbi.nlm.nih.gov database.

Scanning Electron Microscopy-Electron Dispersion X-ray (EM-EDX) analysis

The bacterial isolates were cultured on agar plates amended with $5 \mathrm{mmol}$ $\mathrm{K}_{2} \mathrm{Cr}_{2} \mathrm{O}_{7}$ while plates without amendment were used as controls. A block from the agar plate was cut and fixed in $2 \%$ glutaraldehyde vapor at room temperature for 3 hours. Then dehydrated through a series of ethanol solutions $(50,60,70,80$ and 95\%), $15 \mathrm{~min}$ each; twice with $100 \%$ ethanol, $30 \mathrm{~min} /$ time. Then the ethanol was substituted with the acetone. Samples were dried using $\mathrm{CO}_{2}$ critical point drier (Tousimis Audosamdri-815) and then sputters were coated with gold using a Gold Sputter (SPI-Module). Finally, samples were observed by scanning electron microscope (JSM -5500 LV) coupled with an analyzer EDX ZAF quantification (Gandhia et al., 2010). The size of the cells were measured by calculating the average of of twenty sizes $(n=20)$. For confirming the biosorption of chromium on the bacterial cell surface, biosorption was detected in $\mathrm{EDX}$ at $20 \mathrm{kV}$ where $\mathrm{n}=20$. 


\section{Results}

When concentrations of heavy metals $(\mathrm{Cr}, \mathrm{Cd}, \mathrm{Zn}, \mathrm{Pb}, \mathrm{Cu}, \mathrm{Fe})$ in the waste water and skin shaves were measured, results showed that, in general, they were five times higher in the waste water samples compared to those in the skin shaves, except for chromium which was about 175 times higher than that in skin shaves (Table 1).

TABLE 1. Concentrations of heavy metals measured by atomic absorption spectrophotometer in waste water and skin shaves samples.

\begin{tabular}{|c|c|c|c|c|c|c|}
\hline \multirow{2}{*}{ Group } & \multicolumn{6}{|c|}{ Heavy metal (mg/l) } \\
\cline { 2 - 7 } & $\mathbf{C r}$ & $\mathbf{C d}$ & $\mathbf{Z n}$ & $\mathbf{P b}$ & $\mathbf{C u}$ & $\mathbf{F e}$ \\
\hline $\mathrm{A}$ & 1008.0 & 0.071 & 1.072 & 0.25 & 0.487 & 0.515 \\
\hline $\mathrm{B}$ & 5.73 & 0.035 & 0.679 & 0.16 & 0.138 & 0.139 \\
\hline
\end{tabular}

(A): Waste water group (B): Skin shaves group

Isolation and purification of chromate tolerant bacteria

Total bacterial numbers (as CFU/g) of raw tannery effluents for samples of both groups $\mathrm{A}$ and $\mathrm{B}$ were recorded; the $\mathrm{CFU}$ ranged between $7.2 \times 10^{4}$ and 2.4 $\mathrm{x} 10^{5}$, respectively. The CFU from tannery effluent was lower than that found in the sterile soil $\left(7.8 \times 10^{7}\right)$ Cultivation on chromium amended plates containing $(5,10$ and15) mmol resulted in reducing the number of colonies as the chromium concentration increases. Four percentages of the $\mathrm{CFU}$ (of group $\mathrm{A}$ and $1 \%$ of group B samples were resistant to $15 \mathrm{mmol}$ of chromium (Fig.1).

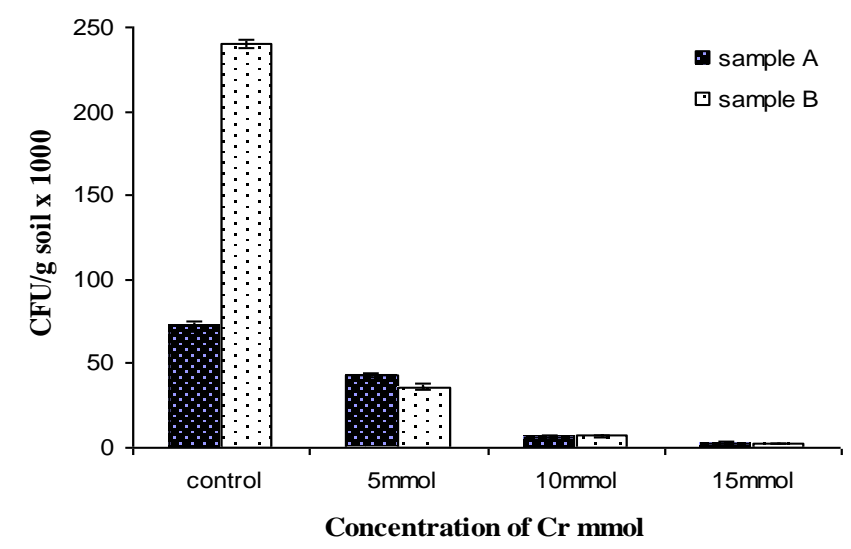

Fig. 1. Total colony forming units (CFU/ g) of samples A and B cultivated on LB medium amended with Cr IV concentrations ranging from 5 to $15 \mathrm{mmol}$.

Egypt. J. Bot., 54, No.1 (2014) 
Only five morphotypes (CrB1, CrB4, CrB7, CrB10 and Cr05) were able to grow on plates amended with $15 \mathrm{mmol}$ chromium. They were selected and grown on LB broth medium containing $\mathrm{Cr}$ averaging a range from 5 - $30 \mathrm{mmol}$ (Fig. 2). The two most resistant isolates, designated $\mathrm{Cr}$ B7 and $\mathrm{Cr} \mathrm{O} 5$, were selected for further studies.

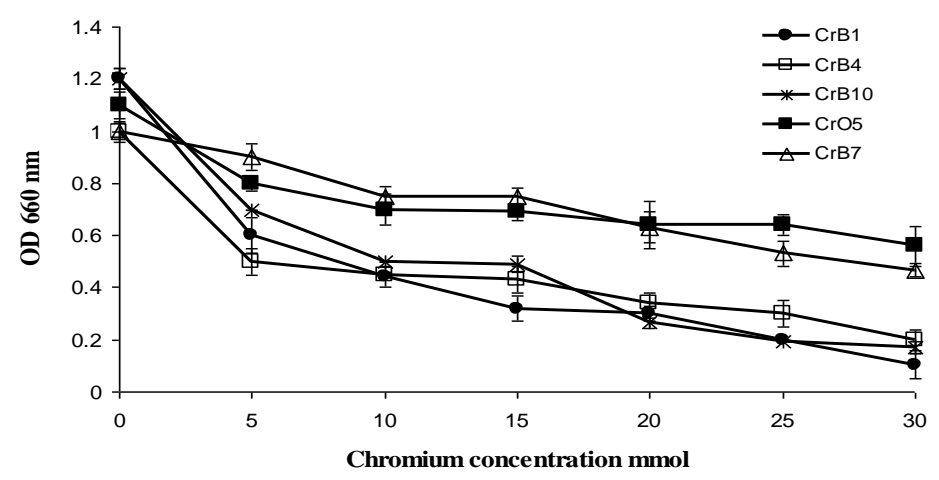

Fig. 2. Effect of increasing $\mathrm{Cr}$ concentration on growth of the five chromium tolerant isolates.

Chromium uptake by the most tolerant isolates

The selected isolates $\mathrm{CrB} 7$ and $\mathrm{CrO} 5$ were grown on $\mathrm{LB}$ broth containing an initial concentration of $15 \mathrm{mmol}(4412 \mathrm{mg} / \mathrm{l}) \mathrm{K}_{2} \mathrm{Cr}_{2} \mathrm{O}_{7}$ before incubation for $30 \mathrm{hr}$. The uptakes of chromate were measured at time intervals. Results declared that the maximum uptake was observed after $24 \mathrm{hr}$ of incubation; the amount of chromium found in culturw supernatant was reduced by $59.8 \%$ and $45.8 \%$ using $\mathrm{Cr} \mathrm{B} 7$ and $\mathrm{Cr} \mathrm{O} 5$ respectively.

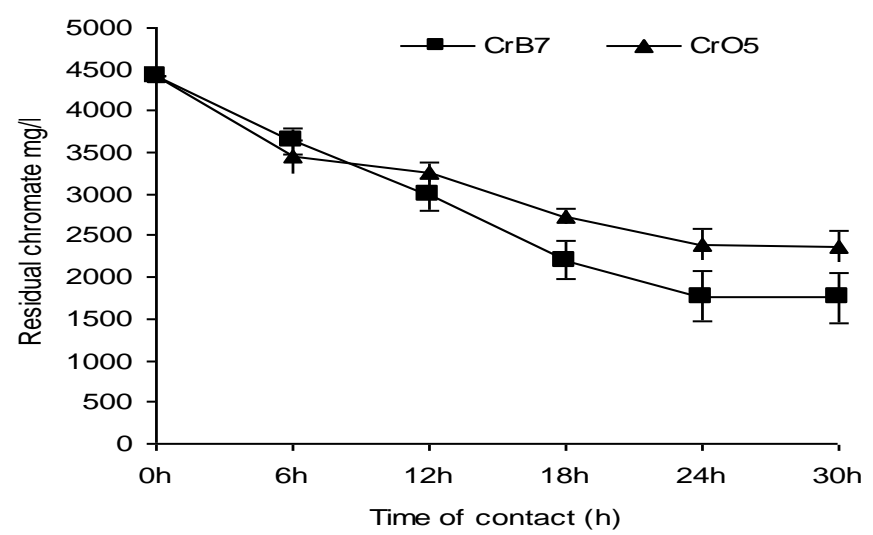

Fig. 3. Chromium uptake by tolerant isolates $\mathrm{CrB} 7$ and $\mathrm{CrO5}$ of what? 
Phenotypic and genotypic characteristics of the isolates

The bacterial colonies of CrB7 were circular, smooth and creamy. The strain was Gram positive, rod-shaped with $(1.4 \mathrm{x} 0.63 \mathrm{~mm})$. Spores are located centrally. While the bacterial colonies of $\mathrm{CrO} 5$ were smooth, glistening, circular and orange in color. The isolate was Gram positive non motile none sporulating with $(0.640$ $\mathrm{mm})$ in diameter. Physiological characteristics for both strains are presented in (Table 2). Interestingly, both isolates were found to tolerate $20 \% \mathrm{NaCl}$ as $\mathrm{NaCl}$ is used in leather treatment process. Partial sequence of 16S rRNA gene of $\mathrm{CrB} 7$ indicated that its blast identity was $99 \%$ similar to Bacillus tequilineis. The sequence was given accession number ( KC631633) and the phylogenetic tree indicated that it grouped with $B$. tequilineis with boot strap value $58 \%$ (Fig4). Strain CrO5 was given accession number (KC631632) and the sequence was 99\% identical to Planococcus citreus. The Neighbor joining phylogenetic tree revealed its grouping with $P$. citreus with $76 \%$ bootstrap value (Fig. 4).

TABLE 2. Physiological characteristics of isolates CrB7 and CrO5.

\begin{tabular}{|c|c|c|c|c|c|c|c|}
\hline Isolate & oxidase & Catalase & $\begin{array}{c}\text { NO3 } \\
\text { reduction }\end{array}$ & $\mathbf{H} \mathbf{S}$ & $\begin{array}{c}\text { Tolerance to } \\
\mathbf{2 0 \%} \mathbf{~ N a C l}\end{array}$ & citrate & $\begin{array}{c}\text { Starch } \\
\text { hydrolysis }\end{array}$ \\
\hline $\mathrm{CrB} 7$ & + & + & + & - & + & + & - \\
\hline $\mathrm{CrO} 5$ & - & + & + & - & + & - & - \\
\hline
\end{tabular}

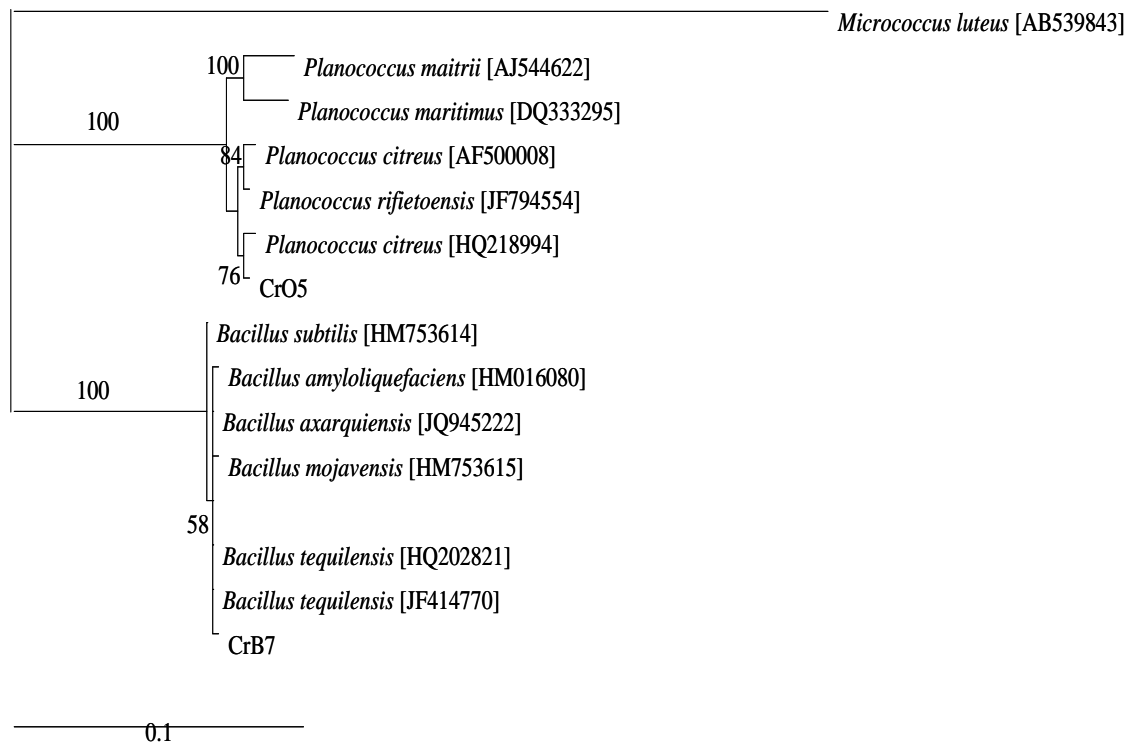

Fig. 4. Neighbor joining phylogenetic tree of partial 16S rRNA sequence of chromium resistant isolates $\mathrm{CrB} 7$ and $\mathrm{CrO5}$. The scale bar represents $10 \%$ nucleotide substitutions. Percentages of bootstrap values recovered from 100 trees are presented on the nodes.

Egypt. J. Bot., 54, No.1 (2014) 
SEM-EDX findings

SEM photographs of $\mathrm{CrB} 7$ and $\mathrm{CrO} 5$ isolates taken before and after $\mathrm{Cr}(\mathrm{VI})$ exposure are presented in (Fig. 5). SEM results revealed that the cells in chromium free medium appeared to have smooth surfaces in a loosely-bound form. When chromium was added to the growth medium, insoluble particles were deposited in the form of amorphous substances which aggregated all over cell surface. Analysis of the energy dispersion X-ray showed that these particles were rich in chromium (Fig. 6).
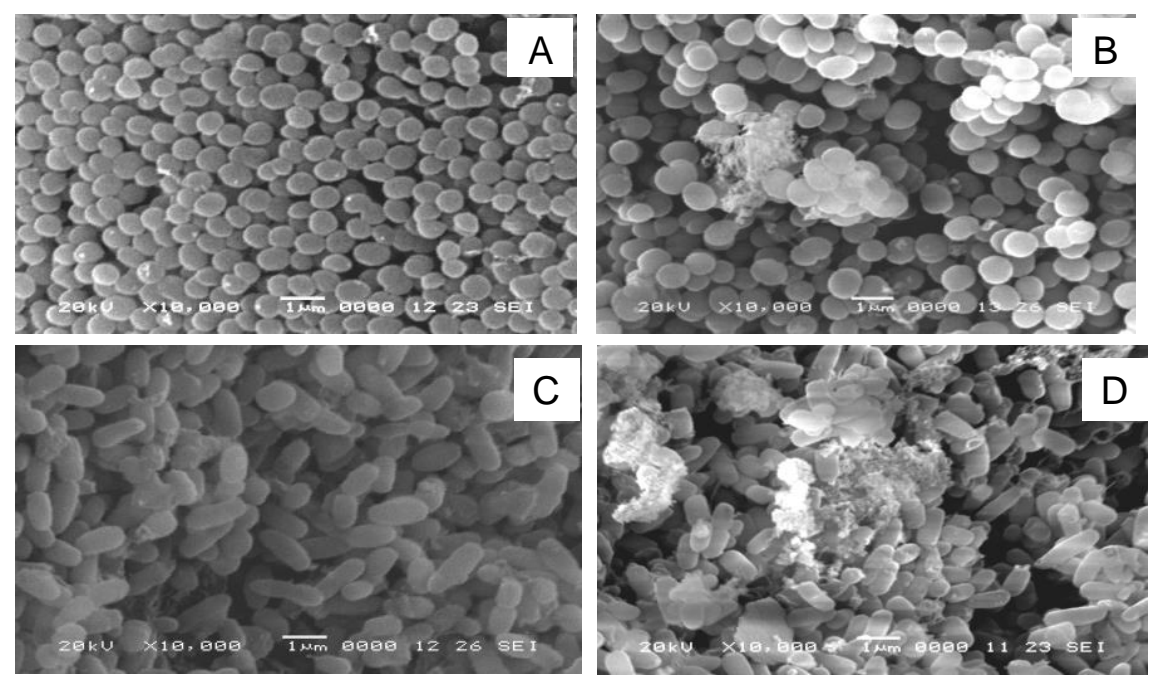

Fig. 5. SEM photograph; (A) CrO5 control, (B) CrO5 treated with CrVI, (C) CrB7 control and (D) CrB7 treated with $\mathrm{Cr}(\mathrm{VI})$.
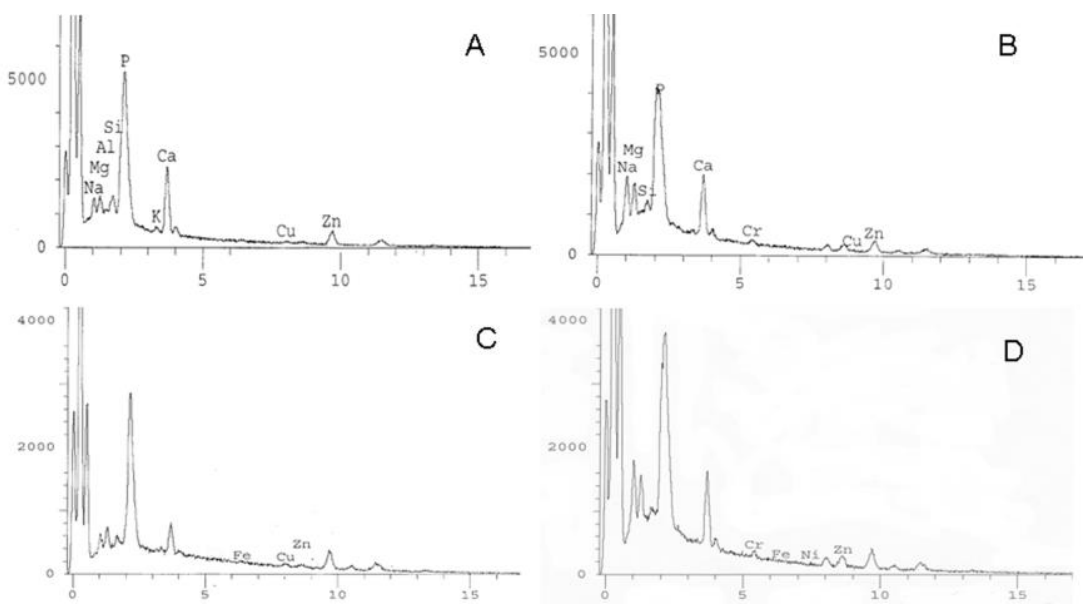

Fig. 6. EDX spectra of $\mathrm{CrB} 7$ and $\mathrm{CrO5}$ isolates, (A) control $\mathrm{CrB7}$, (B) treated CrB7, (C) control CrO5 (D) treated CrO5. 


\section{Discussion}

Continuous discharge of chromium containing wastes used in tannery industries in the area of Magraa Al- Oyoun, Cairo, Egypt resulted in prolonging the exposure of to high concentration of chromium. Concentration of chromium in the collected samples was 5.7 and $1008 \mathrm{mg} / \mathrm{l}$ in groups A, B, respectively. According to Saboor and Aly (2000), soils of industrial areas in Egypt show significant accumulation of metals and several orders of magnitude increase in the concentration above the permissible levels. They recorded that the permissible level of chromium ranges between (75-100) ppm. Rich chromium soil provided an enrichment environment for the selection of potent chromium resistant bacteria. Moreover, high concentration of chromium represents a stress factor that reduces microbial diversity as a result of selective pressure. Few resistant bacteria were dominated in such contaminated areas. In this study, comparison between the sterile soil sample and the chromate contaminated samples revealed lower diversity in chromate contaminated samples which led to domination of only five distinctive morphotypes. Microscopic examination indicated that shape of 4 isolates (B1, B5 B7 and B10) were bacilli and only one isolate (Cro5) was coccid. Similar results were reported by Kamala-Kannan et al., (2007) and Rehman et al., (2008) when they found that Bacillus spp. were dominant in the chromium contaminated sites.

The two isolates selected in this study were found to tolerate high concentrations of what? reaching $30 \mathrm{mmol}$ when grown in the LB medium. Mergeary (1995) reported that this medium could complexes itself with the chromate and / or reduces it; this could indicate that the isolated bacteria could be resistant to even higher concentrations of chromate in its natural environment.

Resistance and tolerance to chromate is common among Gram positive and Gram negative bacteria (Mishra et al., 2012; Minyan et al., 2010; Pei et al., 2009; Desai et al., 2008).

To the best of our knowledge, it is the first time to isolate halotolerant Bacillus tequielnsis and Planococcus citreus isolates that are simultaneously resistant to $\mathrm{Cr}$ VI (30mmol) and other heavy metals. Verma et al. (2009) reported that chromate resistant bacilli were found to be tolerant to multiple metals found in the developing biological treatment of waste water containing chromium and several other metals.

Results of scanning electron micrographs indicated accumulation of chromium on the chromium treated cells of Bacillus tequielnsis and Planococcus citreus. In a similar study, $\mathrm{Cr}(\mathrm{IV})$ reduction outside microbial cells generated the insoluble $\mathrm{Cr}$ (III) ions that unable to cross the cellular membranes (Cervantes et al., 2001). Ehrlish (2002) suggested a possible mechanisms of chromate resistance by Bacillus tequielnsis and Planococcus citreus depending on their ability to reduce chromium (VI) to (III) which precipitates as hydroxides $\left[\mathrm{Cr}(\mathrm{OH})_{3}\right]$ or $\left(\mathrm{Cr}_{2} \mathrm{O} . \mathrm{H}_{2} \mathrm{O}\right)$. Furthermore, exposure to the chromate resulted in the enlargement of bacterial

Egypt. J. Bot., 54, No.1 (2014) 
cells. Almost similar observation was recorded by Ackerley et al., (2006) and Yang et al., (2007). The later found that cells of Enterobacter cloacae cell were elongated after $24 \mathrm{hr}$ incubation in $400 \mathrm{mg} / \mathrm{l}$ chromate. From the EDX analysis, chromium peaks were observed on cells grown in presence of chromium. Similar results were demonstrated also by Pei et al., (2009).

The chromate concentration used in this study $(15 \mathrm{mM})(4400 \mathrm{mg} / \mathrm{l})$ was relatively higher than that previously studied. Previous study mentioned that the rate of $\mathrm{Cr}(\mathrm{VI})$ reduction is dependent on the initial concentration of chromium used a well as on the total bacterial load. According to Ma et al., (2007) and Opperman et al., (2008), the time required to reduce chromate varies from 2-9 days among different bacterial species tested. It took the isolates selected in this study $24 \mathrm{hr}$ to reduce the initial concentration of $15 \mathrm{mmol}$ by 59.8 and $45.8 \%$ for Bacillus tequielnsis and Planococcus citreus, respectively, Therefore, both isolates provided potential tools for removal of toxic elements from water and characterized high salt and multi-metal loads.

Further investigation is required to elucidate the mechanism of chromate reduction by Bacillus tequielnsis and Planococcus citreus.

\section{References}

Ackerley, D.F., Barak, Y., Lynch, S.V., Curtin, J. and Martin, A. (2006) Effect of chromate stress on Escherichia coli K-12. J. Bacteriol., 188, 3371-3381.

Aravindhan, R., Sreeram, K.J., Rao, J.R. and Nair, B.U. (2007) Biological removal of carcinogenic chromium (VI) using mixed Pseudomonas strains. J. Gen. Appl. Microbiol., 53, 71-79.

Asatiani, N.V., Abuladze, M.K., Kartvelishvili, Bakradze, N.G., Spojnikova, N.A., Tsibakhashvili M.K., Tabatadze, L.V., Lejava, L.V., Asanishvili, L.L. and Holman, H.Y. (2004) Effect of chromium(VI) action on Arthrobacter oxydans. Curr. Microbiol., 49, 321-32.

Baldi, F., Vaughan, A. and Olson, G. (1990) Chromium (VI)-resistant yeast isolated from a sewage treatment plant receiving tannery wastes. Appl. Environ. Microbiol., 56, 913-918.

Becquer, T., Quantin, C. Sicot, M. and Boudot, J.P. (2003) Chromium availability in ultimafic soils from New Caledonia. Sci. Total. Environ., 301, 251-261.

Camargo, F.A.O., Okeke, B.C., Bento, F.M. and Frankenberger, W.T. (2004) Hexavalent Chromium reduction by immobilized cells and cell-free extract of Bacillus sp. ES29. Biorem. J., 8, 23-30.

Cervantes, C., Campos-García, J., Devars, S., Gutiérrez-Corona, F., Loza-Tavera, H., Torres-Guzmán, J.C. and Moreno-Sáncez, R. (2001) Interactions of chromium with microorganisms and plants. FEMS Microbiol. Rev., 25, 335-347. 
Costa, M. and Klein, C.B. (2006) Toxicity and carcinogenicity of chromium compounds in Human. Crit. Rev. Toxicology, 36, 155-163.

De Flora, S. (2000) Threshhold mechanism and site specificity in chromium (VI) carcinogenesis. Carcinogenesis, 21, 533-541.

Desai, K. and Madamwar, J.D. (2008) Evaluation of in vitro $\mathrm{Cr}(\mathrm{VI})$ reduction potential in cytosolic extracts of three indigenous isolated from $\mathrm{Cr}(\mathrm{VI})$ polluted industrial landfill. Bioresour. Technol., 99, 6059-6069 .

Edwards, U., Rogall, T., Blocker, H., Emde, M. and Bottger, E. (1989). Isolation and complete nucleotide determination of entire genes. Characterization of a gene coding for 16S ribosomal RNA. Nucleic Acids Res., 17, 7843-7853.

Ehrich, H.L. (2002) How microbes mobilize metals in ores: A view of current understanding and proposal for further research. Miner Metall Process, 19, 220-224.

Gandhia, M.R., Viswanathanb, N. and Meenakshia, S. (2010) Adsorption mechanism of hexavalent chromium removal using Amberlite IRA 743 resin. Ion. Exchange Lett., 3, 25-35.

Ganguli, A. and Tripathi A.K. (2002) Bioremediation of toxic chromium from electroplating effluent by chromate reducing Pseudomonas aeruginosa A2 Chr in two bioreactors. Appl Microbiol. Biotechnol., 58,416-420.

Kamala-Kannan S., Krishnamoorthy, R., Lee K.J., Purusothaman, A., Shanthi, K., and Rao, N.R. (2007) Aerobic reducing Bacillus cereus isolated from the heavy metal contaminated ennore creek sediment, North of Chennai, Tamil Nadu, South East India. Res. J . Microbiol., 2, 133-140.

Lira-Silva, E., Ramírez-Lima, Olín-Sandoval, V., García- Garcia, J.D., GarcíaContreras, R., Moreno-Sánchez, R. and Jasso- Chávez, R. (2011) Removal, accumulation and resistance to chromium in heterotrophic Euglena gracilis. J. Haz. Mat.,193, 216-224.

Liu, Y.G., Xu, W.H., Zeng, G.H., Li, X., Geo, H. (2006) Cr(VI) reduction by Bacillus sp. isolated from Chromium landfill. Process Biochem ., 41 (9), 1981-1986.

Lovely, D.R. and Philips, E.J.P. (1994) Reduction of chromate by Desulfovibrio vulgaris and its C3 cytochrome. Appl. Environ. Microbiol., 60, 726-728.

Ma, Z., Zhu, W., Long, H., Chai, L. and Wang Q. (2007) Chromium reduction by resting cells of Achromobacter sp.Ch-1 under aerobic conditions. Process Bioche., $\mathbf{4 2 ,}$ 1028-1032.

Mabbett, A.N. and Macaskie, L.E. (2001) A novel isolate of Desulfovibrio sp. with enhanced ability to reduce Cr(VI). Biotechnol. Lett., 23 (9), 683-687.

Megharaj, S., Avudainayagam, S. and Naidu, R. (2003) Toxicity of hexanalent chromium and its reduction by bacteria isolated from soil contaminated with tannery waste. Curr. Microbiol., 47, 51-54.

Egypt. J. Bot., 54, No.1 (2014) 
Mergeay, M. (1995) Heavy metal resistances in microbial ecosystems. microbial ecology manual. Kluwer Academic, Netherlands, pp 1-17.

Minyan, H., Xiangyang, L., Liang, G. and Susan, M.J. (2010) Characterization and genomic analysis of chromate resistant and reducing Bacillus cereus strain SJ1. BMC Microbial., 10 (1), 22.

Mishra, R., Sinha, V., Kannan, A. and Raj, K.U. (2012) Reduction of chromium-VI by chromium resistant lactobacilli: Aprospective bacterium for bioremediation. Toxicol. Int., 19, 25-30.

Myers, C.R., Carstens, B.P., Antholine, W.E. and Myers, J.M. (2000) Chromium(VI) reductase activity is associated with the cytoplasmic membrane of anaerobically grown Shewanella putrefaciens MR-1. J. Appl. Microbiol., 88, 98-10.

Opperman, D.J., Piater, L.A. and Heerden, E. (2008) A novel chromate reductase from Thermus scotoductus SA-01 related to old enzyme. J. Bacteriol., 190, 3076-3082.

Park, C.H., Keyhan, M, Wielinga, B., Fendorf, S. and Matin, A. (2000) Purification to homogeneity and characterization of a novel Pseudomonas putidachromate reductase. Appl. Environ. Microbiol., 66 (5), 1788-1795

Pattanapipitpaisal, P., Brown, N.L. and Macaskie, L.E. (2001) Chromate reduction and 16s rRNA identification of bacteria isolated from $\mathrm{Cr}(\mathrm{VI})$-contaminated site. Appl. Microbial. Biotechnol., 57, 257-261.

Pei, Q.H., Shafinaz, S., Raj, A.S.S., Zakaria, Z.A. and Ahmad, W.A. (2009) Chromium(VI) resistance and removal by Acinetobacter haemolyticus. World J. Microbiol.Biotechnol., 25, 1085-1095.

Rehman, A., Zahoor, A., Muneer, B. and Hasnain, S. (2008) Chromium tolerance and reduction potential of Bacillus sp.ev3 isolated from metal contaminated wastewater. Bull. Environ. Contam. Toxicol., 81, 25-29.

Saboor, A.M.F. and Aly, R.O. (2000) Bioremediation of heavy metal contaminated soils in dry land. Case studies in Egypt, In: "Bioremediation of Contaminated Soils". Wise et al., (Ed.). Pub Marcel Dekker Inc, New York. Chapter 39 pp: 677-692.

Shakoori, A.R., Makhdoom, M. and Haq, R.U. et al., (2000) Hexavalent Chromium reduction by a dichromate resistant Gram-positive bacterium isolated from effluents of tanneries. App. Microbiol. Biotechnol., 53, 348-351.

Thacker, U., Parikh, R., Shouch, y., and Madanwar, D. (2006) Hexavelent chromium reduction by Providencia sp. Process Biochem., 41, 1332-1337.

Vaimajala, S., Peyton, B.M., Apel, W.A. and Petersen, J.N. (2002) Chromate reduction by Shewanella oneidensis M.R-1 is an inducible process associated with anaerobic growth. Biotechnol. Prog., 18, 290-296.

Verma, T., Garg, S.K. and Ramteke, P.W. (2009) Genetic correlation between chromium resistance and reduction in Bacillus brevis isolated from tannery effluent. $J$. App. Microbiol., 107, 1425-1432. 
Yang, C., Cheng, Y., Ma, X., Zhu, Y., Holman, H., Lin, Z. and Wang, C. (2007) Surface-mediated chromate resistant mechanism of Enterobacter cloacae bacteria investigated by atomic force microscopy. Langmuir., 23, 4480-4485.

(Received 29/10/2013;

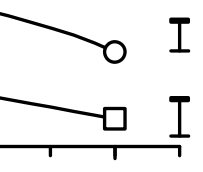

10

\section{الإدمصاص الحيوي للكروم سداسي التكافؤ باستخدام بكتريا معزوله من مخلفات الاباغه الغتيه بالملح}

\author{
ايناس حامد الثطورى و سحر طلبه محمد

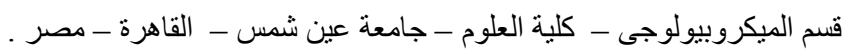

